\title{
Tectonically Induced Deep-Seated Gravitational Slope Deformations and Large Landslides in the Central Adriatic Coastal Belt (Southern Marche-Abruzzi, Italy)
}

\author{
Fubelli $\mathrm{G}^{1 *}$ and Dramis $\mathrm{F}^{2}$ \\ ${ }^{1}$ Department of Earth Sciences, Torino University, Italy \\ ${ }^{2}$ Roma Tre University, Italy
}

*Corresponding author: Giandomenico Fubelli, Department of Earth Sciences,

\section{Short Communication \\ Volume 2 Issue 3}

Received Date: April 18, 2018

Published Date: May 24, 2018

DOI: $10.23880 /$ jenr-16000132

University of Torino, Via Valperga Caluso 35, Torino 10125, Italy, Tel: 00393737265088; Email: giandomenico.fubelli@unito.it

\section{Abstract}

This short note deals with the relationships between the large landslides that recurrently affect the Plio-Pleistocene clayey bedrock and the overlying marine conglomerates along the central Adriatic coast. This coastal sector is affected by regional uplift and tectonic shortening that gives rise to elongated topographic highs grown above buried compressive structures along which the investigated coastal sector has formed. The landslides are related to a particular mechanism of deep-reaching lateral spread, induced by the interaction of surficial tectonic deformation and gravitational stress.

Keywords: Coastal landslides; Deep-seated gravitational slope deformations; Active tectonics; Adriatic coast, Italy

\section{Introduction}

The central Adriatic coastal belt (southern MarcheAbruzzi-Molise, Italy) extends for about $220 \mathrm{~km}$ between Porto Recanati and Vasto trending approximately parallel to the Apennine chain (fig. 1). It is largely sided by slopes that culminate at altitudes up to some hundred meters and are bordered downward by cliffs up to $200 \mathrm{~m}$ high, interrupted by the wide outlet valleys of the main rivers.
The geo-structural setting of the central peri-Adriatic belt is large part by eastward verging blind thrusts, buried under an up to some $\mathrm{km}$ thick post-orogenic sequence of siliciclastic units ranging in age from the Lower Pliocene to the Middle Pleistocene p.p. [1]. These buried structures are parallel to the Apennine thrusts and are still active basing on geomorphological evidence $[2,3]$ and recurrent earthquakes.

From Porto Recanati to Petacciato (Figure 1), the coastline extends along topographical highs ("coastal 


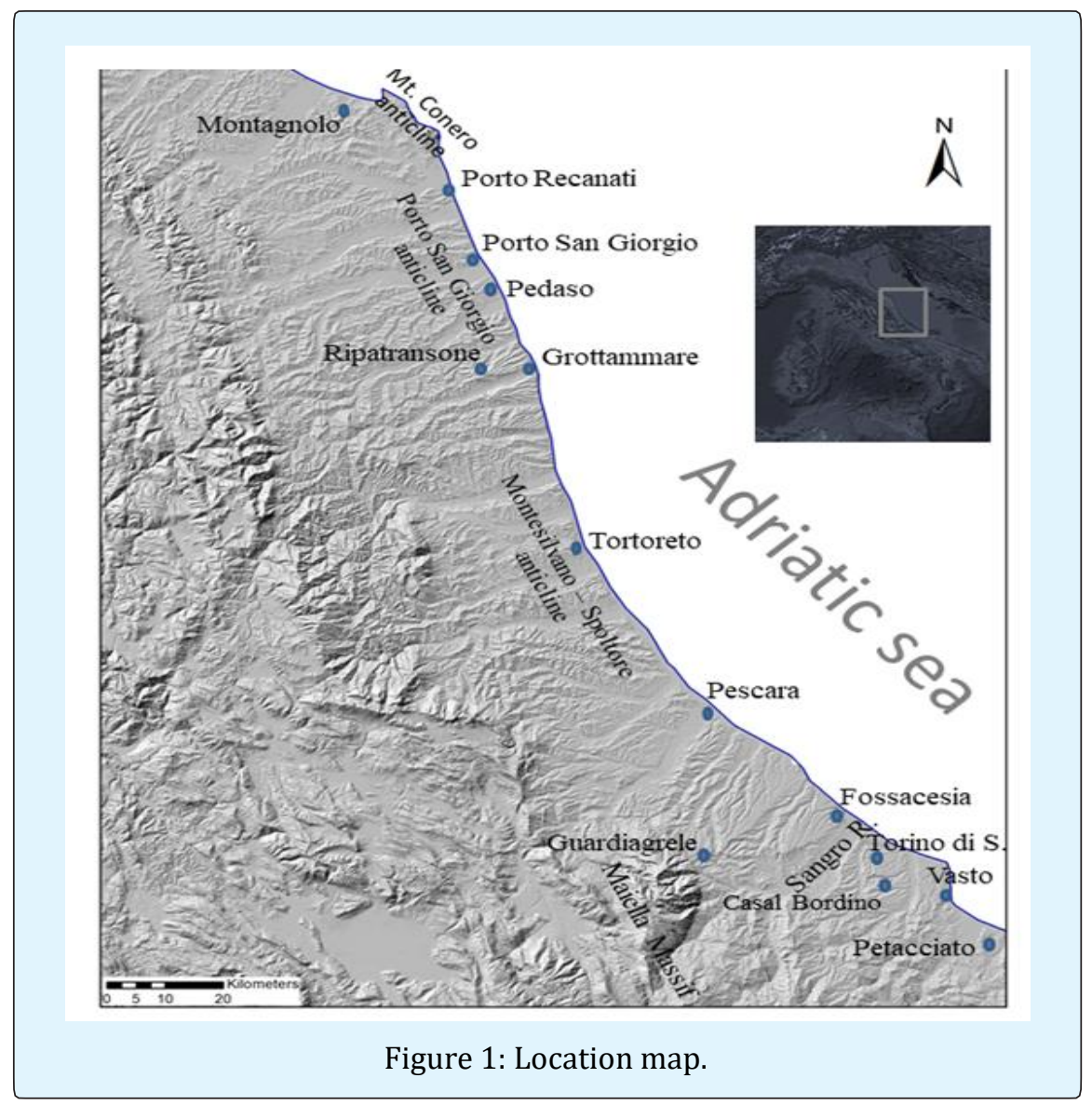

The outer flanks of the more elevated sectors of the coastal ridges are affected by gravitational phenomena that locally involve huge masses of stratified clayey sediments inducing heavy risk conditions to the densely populated coastal belt, characterized by the presence of important urban centers and crossed by strategic infrastructures such as a motorway and a railway line.

This short note examines the geomorphological characteristics, the triggering factors and the evolutionary modalities of these phenomena.

\section{Geological-Geomorphological Framework of the Peri-Adriatic Coastal Belt}

The geological bedrock outcropping in the central periAdriatric belt consists essentially of Upper PlioceneLower Pleistocene, transgressive-regressive clayey-sandy sediments with minor conglomerate intercalations $[1,4,5]$ locally overlain by Middle Pleistocene sandy- conglomeratic coastal deltaic deposits (closing deposits of the marine succession). These deposits, emplaced in association with the growth of the outer Apennine ridges, cover Upper Miocene evaporitic and clastic sediments overlying platform carbonates "Apulian Domain" [6] that crop out in the inner Apennine ridges and at the Mt. Conero anticline, immediately north of the investigated coast sector. More to the south, between the Sangro River and Guardiagrele, the "Allochthonous Molisano", a gravitational tectonic melange of varicolored shales, pelagic limestones, and flysch (Cretaceous to Messinian p.p. in age), is inserted between the pre-Pliocene basement and the Plio-Pleistocene sedimentary cover [7].

Blind compressive structures, buried under the Upper Pliocene-Middle Pleistocene post-orogenic stratigraphic sequence and generally aligned according the Apennine direction, have been recognized in the central Adriatic coastal sector, from the Apennine front to the coast, and more to the east, in the offshore [6,8,9]. Detailed 


\section{Journal of Ecology \& Natural Resources}

information on the blind structures is provided by the deep-reaching geognostic investigations carried out by oil companies in the peri-Adriatic belt [6].

The recent to present activity of the buried structures is evidenced by the growth above them of elongated topographic highs, affected by tectonic dislocations generally corresponding to the buried ones $[2,10]$. One of these highs overlying a blind structure, that represents the southern continuation of the Mt. Conero anticline, extends along the Adriatic coast, from Porto Recanati to Pescara [1]. More to the south, this structure deviates sharply inwards and the coastline develops over another one, more advanced to the east as it occurs backward to the Apennine front (Maiella Massif), with the growth of a new coastal ridge [1,2]. A further coastal ridge, set back from the previous one, develops between Vasto and Petacciato.

The present incidence of compressive tectonics is also evidenced by the occurrence of earthquakes with a compressive hypocentral mechanism, such as the Porto San Giorgio ( $M=4.9$ ) seismic event of July 3, 1987 [11] and the seismic sequence $(M=4.4-49)$ that has struck Ancona from February 4 to June 18, 1972 [12].

The Plio-Pleistocene post-orogenic sediments are well stratified and are arranged, on the whole, according to a monoclinal structure with a general dip towards NE and ENE and attitude from $18-20^{\circ}$ inwards to $10-12^{\circ}$ or less near the coast. This structural setting is the consequence of a regional uplift that, starting from the end of the Lower Pleistocene, has involved the entire peri-Adriatic belt [13]. Transverse faults, already present in the prePliocene basement, albeit with changing movements over time, have subdivided the area into sectors characterized by different uplift rates [13] raising the depositional surfaces of the Middle Pleistocene deposits up to $508 \mathrm{~m}$ a.s.l. at Ripatransone (12 km far from the coastline) and $598 \mathrm{~m}$ a.s.l. at Guardiagrele ( $23 \mathrm{~km}$ far from the coastline) and, due to the growth of the coastal ridges, up to more than $200 \mathrm{~m}$ a.s.l. along the coast $(266 \mathrm{~m}$ a.s.l. at Tortoreto). In the more uplifted sectors, well developed anticlines (Porto San Giorgio and Montesilvano-Spoltore anticlines) are recognizable along the "coastal ridges". The uplift has continued till recent Quaternary times as indicated by the longitudinal convergence of alluvial terraces in the SW-NE river valleys [14]. This phenomenon is part of a large-scale transverse arching that has involved the entire Italian peninsula giving rise to the present Apennine chain. The lift amplitudes have attained values of $1500-2000 \mathrm{~m}$ as evidenced by the elevation reached by planation surfaces and terraced deposits correlated with Pleistocene sea levels [15-18].

The landscape of the coastal belt is characterized by a hilly relief whose altitude gradually decreases from the Apennine front to the Adriatic coast. On top of the hills, remnants of a wide planation surface gently dipping eastward, uplifted and deeply incised by river valleys, are locally recognizable. This surface, due to pedimentary erosion of the Apennine piedmont in the first uplift stages and previously referred to the Villafranchian by Demangeot [15], is presently considered post-Sicilian in age because of its correlation with marine sediments near the Adriatic coast $[13,19]$.

The valley network includes three to four main orders of terraces, the highest of which date to the Middle Pleistocene and the lowest to the Upper Pleistocene [14]. Their genesis is referred to the cold climatic oscillations that occurred in the area during the valley deepening and, in particular, to the marked increase in the debris supply to the fluvial waters from the bare slopes, widely affected by frost-shattering, slope wash and solifluction [20]. Fluvial terraces of Holocene age referable, at least in part, to anthropic deforestation are present in the river valleys [21]. In the distal reaches of the rivers, there are also terraces linked to the late Quaternary high stands of sea level, whose corresponding coastal terraces are scarcely present on the coastal slopes due to the widespread occurrence of landslides. Where present in the study area, the stepped terraces reflect the interplay between tectonics (uplift) and sea level changes, in which terraces define episodes of relative sea level fall during the late Quaternary and the tectonic vertical movements produce the progressive uplift of the coastal ridges and the consequent migration toward east of the coastline.

The last post-glacial sea level rise filled the river mouth valleys covering the previous "glacial" (Wurm) fluvial deposits. This event has largely changed the geomorphological and geobiological setting of the "glacial" coastal landscape, bringing the coastline to its current position.

\section{The Genetic-Evolutionary Context of Coastal Landslides}

As mentioned above, the slopes that border the central Adriatic coast, constantly modeled on Plio-Pleistocene clays (over-consolidated materials composed of a mixture of clay and silt with shear resistance ranging between 60 and $180 \mathrm{kP}$; [22] surmounted by Middle Pleistocene 


\section{Journal of Ecology \& Natural Resources}

conglomerates are affected by landslides of large dimensions (displaced mass up to more than 100 million $\mathrm{m}^{3}$, fronts extended up to more than $1 \mathrm{~km}$, and sliding surfaces up to more than $100 \mathrm{~m}$ deep). These phenomena are characterized by a roto-translational movement developed on several levels and show a step-like evolution, with long periods of quiescence alternating with brief reactivation phases [23]. Some of them (Pedaso, Grottammare, Fossacesia, Torino di Sangro, Casal Bordino, Vasto and Petacciato landslides) have undergone several reactivation events from historical times to recent years, as shown by direct observations and archival documents [24-30].

Coastal erosion has repeatedly activated the gravitational movements during the Middle Pleistocene (since ca. 215 ka BP), giving rise to coastal cliffs [29]. After the Tyrrhenian stage, when the sea level was considerably higher than the present, wave erosion could not reach anymore the base of the cliffs, that are separated from the coastline by a sandy-gravelly strip up to several hundreds of meters wide.

Excluding coastal erosion, the only possible historical and current reactivation factors are intense and prolonged rainfall, as it was actually observed for the investigated landslides $[24,25,29,30]$, and seismic shocks, as inferred in the case of the most recent reactivation of the Ancona coastal landslide, immediately north of the investigated coastal sector [31].

According to most authors, the litho-structural characteristics of Plio-Pleistocene clayey deposits represent the predisposing factors of the large landslides. Some contribution of active tectonics has been hypothesized by Guerricchio [26] and, more recently, by Doglioni, et al. [32].

Escarpments and trenches parallel to the shore line and up to more than $1 \mathrm{~km}$ in length, indicating the presence of deep reaching rupture surfaces, interpretable as listric faults induced by the ongoing tectonic deformation of the coastal ridge fronts, are common features along the Central Adriatic coast. They are constantly associated with the large coastal landslides but also appear in sectors not affected by these phenomena [28,33].

Basing on the occurrence on the above features, we believe that the genetic/evolutionary mechanism at the origin of the large landslides is represented by tectonicgravitational spread, a process of tectonically-induced deep gravitational slope deformation described by Dramis \& Sorriso-Valvo [34] and Dramis, et al. [35] for the huge gravitational movement that involved the Montagnolo coastal slope north of Ancona [23].

The tectonic-gravitational evolution of the frontal side of the coastal ridges begins with the superficial deformation induced by tectonic compression and then evolves as a result of gravitational stress in the formation of listric faults and, more externally, of large landslides (Figure 2). This situation characterizes a typical compression-related context along which tectonic efforts are modulated with topographic-gravitational stresses [36-38].

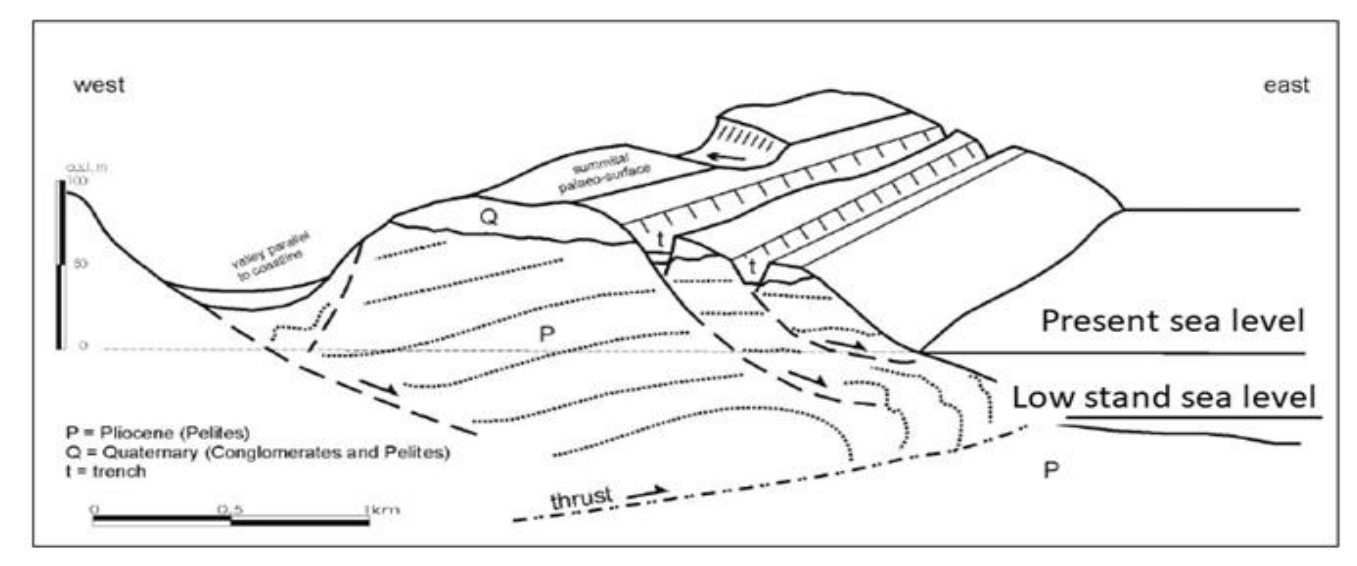

Figure 2: Block diagram showing a evolutionary model, even in relation with the sea level changes (from Aringoli, et al., 2011, modified) [28]. 
In conclusion, the central Adriatic coast develops in correspondence with active tectonic structures along which deep reaching gravitational deformations and related large landslides are formed.

\section{References}

1. Bigi S, Cantalamessa G, Centamore E, Didaskalou P, Dramis F, et al. (1997) La fascia periadriatica marchigiano-abruzzese dal Pliocene medio ai tempi attuali: evoluzione tettonico-sedimentaria e geomorfologica. Studi Geologici Camerti 1995(1): 3749.

2. Racano S, Fubelli G, Centamore E, Bonasera M, Dramis F (2018) Morphostructural evidences of active tectonics in the southern Abruzzi periadriatic region. Geophysical Research Abstracts, vol. 20, EGU20186645, 2018 EGU General Assembly.

3. Lavecchia G, de Nardis R, Di Naccio D, Ferrarini F, Cirillo D (2015) Active compression in Eastern Abruzzo (central Italy): evidences from geological morphotectonic and macroseismic data analyses. Rendiconti Online Società Geologica Italiana 36(1).

4. Ori GC, Serafini G, Visentin C, Ricci Lucchi F, Casnedi $\mathrm{R}$, et al. (1991) The Pliocene-Pleistocene Adriatic foredeep (Marche and Abruzzo, Italy): an integrated approach to surface and subsurface geology. Third E.A.P.G. Conference., Adriatic foredeep field guidebook, Florence, pp: 85.

5. Centamore E, Rossi D (2009) Neogene-Quaternary tectonics and sedimentation in the Central Apennines. Bollettino Società Geologica Italiana 128(1): 73-88.

6. Patacca E, Scandone P, Di Luzio E, Cavinato GP, Parotto M (2008) Structural architecture of the central Apennines: Interpretation of the CROP 11 seismic profile from the Adriatic coast to the orographic divide. Tectonics, 27, TC3006 27(3): 36.

7. Corrado S, Di Bucci D, Naso G, Giampaolo G, Adatte T (1998) Application of organic matter and clay minerals studies to the tectonic history of the Molise area, Central Apennines. Tectonophysics 285 (1-2): 167-181.

8. Ghisetti F, Vezzani L (1998) Carta Geologica dell'Abruzzo, scala 1:100.000. Regione Abruzzo.

9. Festa A, Ghisetti F, Vezzani L (2006) Carta Geologica del Molise, scala 1:100.000. Note illustrative. Regione Molise.
10. Vannoli P, Basili R, Valensise G (2004) New geomorphic evidence for anticlinal growth driven by blindthrust faulting along the northern Marche coastal belt (central Italy). J Seismology 8(3): 297312.

11. Riguzzi F, Tertulliani A, Gasparini C (1989) Study of the seismic sequence of Porto S Giorgio (Marche) - 3 July 1987. Il Nuovo Cimento C 12(4): 453-466.

12. Kisslinger C (1972) The Ancona, Italy, earthquake swarm. Seismological Research Letters 43(4): 9-16.

13. Dramis F (1992) Il ruolo dei sollevamenti tettonici a largo raggio nella genesi del rilievo appenninico. Studi Geologici Camerti 1992(1): 9-15.

14. Urbano T, Piacentini T, Buccolini M (2017) Morphotectonics of the Pescara River basin (Central Italy). J Maps 13(2): 511-520.

15. Demangeot J (1965) Géomorphologie des Abruzzes Adriatiques. Memoires et Documents du CNRS, Paris, pp: 287.

16. Dramis F, Pambianchi G, Nesci O, Consoli M (1991) Il ruolo di elementi strutturali trasversali nell'evoluzione tettonico-sedimentaria e geomorfologica della regione marchigiana. Studi Geologici Camerti CROP 11(2): 283-286.

17. D’Agostino N, Dramis F, Funiciello R, Jackson JA (2001) Interactions between mantle upwelling, drainage evolution and active normal faulting: an example from the central Apennines (Italy). Geophysical J Internat 147(2): 475-497.

18. Bartolini C, D'Agostino N, Dramis F (2003) Topography, exhumation, and drainage network evolution of the Apennines. Episodes 23(3): 212-217.

19. Coltorti M, Consoli M, Dramis F, Gentili B, Pambianchi G (1991) Evoluzione geomorfologica delle piane alluvionali delle Marche centro-meridionali. Geografia Fisica e Dinamica Quaternaria 14(1): 87-100.

20. Coltorti M, Dramis F (1987) The significance of stratified slope waste deposits in the Quaternary of Umbria-Marche Apennines (Central Italy). Zeitschrift für Geomorphologie Suppl Bd 71: 59-70.

21. Calderoni G, Cilla G, Dramis F, Gobbi C (2007) Environmental changes and human settlement in the Central Marches (Italy) during the Early-Middle Holocene. Physio Géo 1: 21-32. 


\section{Journal of Ecology \& Natural Resources}

22. Esu F, Grisolia M (1991) La stabilità dei pendii costieri adriatici tra Ancona e Vasto. In: Esu F (Ed.), Frane Costiere, Università di Roma "La Sapienza", pp: 55-79.

23. Coltorti M, Dramis F, Gentili B, Pambianchi G, Crescenti \& Sorriso-Valvo M (1985) The December 1982 Ancona landslide: a case of deep-seated gravitational slope deformation evolving at unsteady rate. Zeitschrift für Geomorphologie NF 29(3): 335345.

24. Cancelli A, Marabini F, Pellegrini M, Tonnetti G (1984a) Incidenza delle frane sull'evoluzione della costa adriatica da Pesaro a Vasto. Memorie della Società Geologica Italiana 27: 555-568.

25. Cancelli A, Pellegrini M, Tonnetti G (1984b) Geological features of landslide along the Adriatic coast (Central Italy). Proceedings International Symposium on Landslides, Toronto, 2: 7-12.

26. Guerricchio A (1988) Aspetti geologici sull'erosione dei litorali e loro influenza nel campo applicativo. Geologia Applicata e Idrogeologia 23: 29-78.

27. Fiorillo F (2003) Geological features and landslide mechanisms of an unstable coastal slope (Petacciato, Italy). Engineering Geology 67(3-4): 255-267.

28. Aringoli D, Buccolini M, Materazzi M, Gentili B, Pambianchi G, Sciarra N (2012) Large landslides in sea-cliff areas of the central Adriatic coast (Italy). Proceedings of the Second World Landslide Forum, 37 October. 2011, Rome, pp: 2-5.

29. Della Seta M, Martino S, Scarascia-Mugnozza G (2013) Quaternary sea-level change and slope instability in coastal areas: Insights from the Vasto landslide (Adriatic coast, central Italy). Geomorphology 201: 462-478.

30. Sciarra M, Carabba L, Urbano T, Calista M (2016) A multi-disciplinary approach to study coastal complex landslides: the case of Torino di Sangro (Central Italy). Geophysical Research Abstracts, EGU General Assembly 2016(18).
31. Michetti AM, Brunamonte F (2002) Some remarks on the relations between the 1972 Ancona earthquake sequence and the Ancona landslide. In: Comerci V, D’Agostino N, Fubelli G, Molin P, Piacentini T (Eds.), Seismically Induced Ground Ruptures and LargeScale Mass Movements, APAT - Italian Agency for Environment Protection and Technical Services, pp: 31-34.

32. Doglioni A, Galeandro A, Guerricchio A, Simeone V (2015) Tectonic stress as possible co-predisposing factor for landslides along the central Adriatic coast of Italy. In: Lollino G, Giordano D, Crosta GB, Corominas J, Azzam R, Wasowski J, Sciarra N (Eds.), Engineering Geology for Society and Territory, 2.

33. Gentili B, Pambianchi G, Aringoli D, Materazzi M, Giacopetti M (2017) Pliocene-Pleistocene geomorphological evolution of the Adriatic side of Central Italy. Geologica Carpathica 68(1): 6-18.

34. Dramis F, Sorriso-Valvo M (1994) Deep-seated gravitational slope deformations, related landslides, and tectonics. In: Oyagy N, Sorriso-Valvo M, Voight B (Eds.), Deep-Seated Landslides and Large-Scale Rock Avalanches, Engineering Geology 38(3-4): 231-243.

35. Dramis F, Farabollini P, Gentili B, Pambianchi G (1995) Neotectonics and large-scale gravitational phenomena in the Umbria-Marche Apennines, Italy. In: Slaymaker O (Ed.), Steepland Geomorphology. J Wiley \& Sons Chichester pp: 199-217.

36. Colalongo ML, Nanni T, Ricci Lucchi F (1979) Sedimentazione ciclica nel Pleistocene anconetano. Geologica Romana 18: 71-92.

37. Crescenti U (1986) La grande frana di Ancona del 13 dicembre 1982. Studi Geologici Camerti 146.

38. Colalongo, Garbin M, Lavecchia G, Pace B, Peruzza L, et al. (2011) A temporary seismic monitoring of the Sulmona area (Abruzzo, Italy) for seismotectonic purposes. Bollettino di Geofisica Teorica e Applicata 52(4): 651-666.

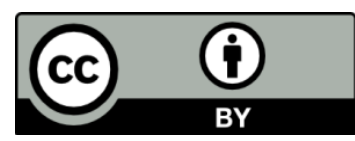

Fubelli G and Dramis F. Tectonically Induced Deep-Seated Gravitational Slope Deformations and Large Landslides in the Central Adriatic Coastal Belt (Southern 